
МАРКЕТИНГОВИЙ СУПРОВІД КОМЕРЦІАЛІЗАЦІЇ
ІННОВАЦІЙНОЇ ПРОДУКЦІї ПІДПРИЄМСТВ

\title{
MARKETING SUPPORT FOR COMMERCIALIZATION INNOVATION PRODUCTS OF ENTERPRISES
}

Удк 658.8.001.76

https://doi.org/10.32843/infrastruct40-76

\section{Ілляшенко С.М.}

д.е.н., профресор,

просресор касредри менеджменту інноваційного підприємництва та міжнародних економічних відносин Національний технічний університет «Харківський політехнічний інститут»; д-р хабілітований, профресор Вища економіко-гуманітарна школа Шипуліна ю.С.

д.е.н., доцент, профресор кафредри економічної кібернетики та маркетингового менеджменту Національний технічний університет «Харківський політехнічний інститут»

\section{Illiashenko Sergii}

National Technical University

"Kharkiv Polytechnic Institute";

University of Economics and Humanities Shypulina Yuliia

National Technical University

"Kharkiv Polytechnic Institute" у статті запропоновано схему управління вибором заходів маркетингового супроводу різних варіантів комерціалізації інноваційної продукції підприємства, що виділені за ступенем охоплення етапів інноваційного й життєвого циклу продуктової інновації. Вона дає змогу узагальнено окреслити коло методів та інструментів маркетингу інновацій, які забезпечують маркетинговий супровід вибраних варіантів комериіалізації. Запропоновано підхід до врахування в заходах маркетингу інновацій особливостей виконання його завдань на етапах життєвого циклу нового товару, а також урахування стану споживчої готовності цільових споживачів, що дає змогу уточнити силу впливу, тривалість і бюджет заходів комплексу маркетингу інновацій. Практична реалізація отриманих результатів дає змогу підвищити есрективність маркетингового супроводу комерціалізації інновацій у сучасних умовах трансформації технологічних укладів і спричинених цим змін вектору впливу фракторів зовнішнього макро- й мікросередовища. Ключові слова: інноваційна діяльність, підприємство, комерціалізація інновацій, мар кетинг інновацій, маркетинговий супровід комерціалізації.

В статье предложена схема управления выбором мер маркетингового сопрово- ждения различных вариантов коммерци ализации инновационной продукции предприятия, которые выделены по степени охвата этапов инновационного и жизненного цикла продуктовой инновации. Она позволяет обобщенно очертить круг методов и инструментов маркетинга инноваций, которые обеспечивают маркетинговое сопровождение выбранных вариантов коммерциализации. Предложен подход к учету в мерах маркетинга инноваций особенностей выполнения его заданий на этапах жизненного цикла нового товара, а также учету состояния потребительской готовности целевых потребителей, что позволяет уточнить силу влияния, дли тельность и бюджет мер комплекса маркетинга инноваций. Практическая реализация полученных результатов позволяет повысить эфрфективность маркетинго вого сопровождения коммерциализации инноваций в современных условиях трансформации технологических инноваций и вызванных этим изменений вектора влияния фракторов внешней макро- и микросреды.

Ключевые слова: инновационная деятельность, предприятие, коммерциализация инноваций, маркетинг инноваций, маркетинговое сопровождение инноваций.

World experience shows that successful innovation depends largely on the stage of commercialization of innovations. And one of the main tools of commercialization is marketing. Accordingly, the purpose of the article is to develop an approach to managing the choice of complex marketing support measures for the commercialization of innovative products. The article describes the variants of the innovation process, distinguished by the degree of coverage of the stages of innovation and life cycle of a new product, and, accordingly, options for commercialization of innovations. Refinements and systematization of problems of marketing of innovations for the selected variants of the innovation process and variants of commercialization of innovations are carried out. It is proved that all works of marketing of innovation can be divided into two types: related to the orientation of innovative activity of the enterprise on creation of perspective innovations, which are aimed at solving current and predicted problems of actual and potential consumers; related to the formation and stimulation of demand for innovation, the promotion of innovation in the market, monitoring the development of the market situation. The marketing tasks of innovation in the life cycle stages of a new product, which depend on the type of consumer (innovators, followers, majority or outsiders), have been clarified. The features of the tasks of marketing of innovations peculiarities of the innovation marketing tasks, according to the state of consumer readiness in which the target consumers of the new product are located (actual or potential), are identified. The scheme of management of choice of measures of marketing support of commercialization of innovative products is developed. This scheme allows us to summarize the range of methods and tools of marketing innovation that provide marketing support for the selected options for commercialization. The practical realization of the obtained results allows increasing the efficiency of marketing support of commercialization of innovations in the conditions of transformation of technological ways. Further research should focus on developing the principles of organizational and economic mechanism of management of commercialization of innovations based on marketing. Key words: innovative activity, enterprise, commercialization of innovations, marketing of innovations, marketing support of commercialization.

Постановка проблеми. Як засвідчує світовий досвід, успіх орієнтованої на ринок інноваційної діяльності головним чином залежить від ефективності її завершального етапу, а саме комерціалізації інновацій. Серед множини фракторів, які впливають на ефективність комерціалізації, одну 3 головних ролей відіграє її маркетингове забезпечення. Інструменти й методи маркетингу інновацій дають змогу визначити тенденції розвитку ринкових процесів, визначити на цій основі інтереси та мотиви поведінки всіх учасників системи створення, виготовлення й просування інновацій на ринку, розробити дієві заходи комплексу маркетингу інновацій. Поточний період транссрормації технологічних укладів і спричинених нею змін умов макро- й мікросередовища актуалізує проблему оперативного реагування на ці зміни та їх урахування у стратегіях інноваційного розвитку, зокрема в тій їх частині, що стосується маркетингового забезпечення комерціалізації інновацій. Надзвичайно гостро ця проблема постає для вітчизняних підприємств, які часто програють

\footnotetext{
${ }^{1}$ Робота виконана за рахунок бюджетних коштів МОН України, наданих на виконання науково-дослідної теми: «Розроблення механізму комерціалізації інноваційної продукції» № ДР $0118 \cup 003572$
} 
зарубіжним конкурентам внаслідок неспроможності оперативно й ефективно комерціалізувати свої інноваційні продукти, що не поступаються зарубіжним аналогам.

Аналіз останніх досліджень і публікацій. Проблематика комерціалізації інноваційної продукції досліджувалася в роботах багатьох науковців. М.П. Бутко, О.В. Попело [1] досліджують підходи до комерціалізації науково-технічних розробок, а також фрактори, що впливають на успіх комерціалізації, серед яких найважливішою вони вважають ефективність маркетингу інновацій. М.П. Калініченко [7] розроблює й науково обґрунтовує рекомендації щодо застосування маркетингового підходу до комерціалізації результатів інноваційної діяльності у промисловості.

O.В. Євтушевська [2] досліджує особливості сприйняття чи несприйняття споживачами товарів новинок, аналізує маніпулятивні технології комплексу маркетингових комунікацій тощо. О.М. Олефріренко [16] аналізує конфрлікти суб'єктів процесу комерціалізації інновацій промислових підприємств, окреслює загрозі, які вони становлять, обґрунтовує необхідність забезпечення узгодженої взаємодії зазначених суб'єктів. Д.В. Тимофеєєв [19] досліджує теоретичні аспекти зміни динаміки економічного еоректу в процесах управління життєвим циклом промислових інновацій на етапі їх комерціалізації.

О.О. Плахотнік [17] аналізує проблеми та особливості фрормування сучасного механізму комерціалізації інноваційних технологій, розглядає основні складові частини механізму комерціалізації інноваційних технологій та особливості їх прояву в Україні. О.М. Олефріренко [15] аналізує передумови та реалії комерціалізації інновацій в умовах України. В.М. Кузьомко [12] аналізує ключові виклики та загрози інноваційній діяльності підприємств України. А.О. Попова [18] розкриває сутність, зміст, перспективи й перешкоди реалізації в Україні моделі так званої потрійної спіралі взаємовідносин університетів, підприємств та уряду в процесі комерціалізації інноваційної продукції, обґрунтовує зростання ролі університетів у цьому процесі. А.В. Карпенко, Ю.С. Кононенко [8] визначає основні фрактори впливу на успіх комерціалізації інноваційної діяльності за рівнем сприятливості, окреслює основні способи комерціалізації та ії етапи, а також порядок взаємодії суб'єктів комерціалізації інновацій. О.П. Косенко [9] розвиває теоретико-методологічні й методичні засади комерціалізації інтелектуально-інноваційних технологій. Н.Ю. Мирощенко [14] розробляє теоретико-методологічні й методичні засади комерціалізації високотехнологічної продукції промислових підприємств.

О.Є. Кузьмін, Р.С. Косцик [11] аналізують форми та відповідні їм методи комерціалізації інноваційної продукції підприємств, зазначають їхні переваги та недоліки, а також фрормують модель вибору методів комерціалізації інноваційної продукції підприємств. Ю.М. Мельник, Л.Ю. Сагер, Л.О. Сигида [13] пропонують способи комерціалізації відповідно до форм інноваційної продукції, а також набір стратегічних альтернатив комерціалізації, виділяють фрактори, що визначають особливості стратегії комерціалізації.

Незважаючи на численні напрацювання, проблема комплексного маркетингового супроводу комерціалізації інноваційної продукції залишається невирішеною. Наявні підходи до визначення варіантів комерціалізації інновацій недостатньо відображають їх специфріку відповідно до ступеня охоплення етапів інноваційного й життєвого циклу, недостатньо висвітленими є завдання маркетингу інновацій для зазначених варіантів комерціалізації, що не дає змогу цілеспрямовано управляти заходами маркетингового супроводу комерціалізації інноваційної продукції на рівні окремих підприємств.

Постановка завдання. Метою статті $€$ розроблення підходу до визначення послідовності та змісту процедур цілеспрямованого й ефективного управління вибором системи заходів комплексного маркетингового супроводу комерціалізації інноваційної продукції підприємств.

Виклад основного матеріалу дослідження. Для досягнення задекларованої мети запропоновано таку послідовність етапів виконання досліджень:

1) уточнення варіантів інноваційного процесу, виділених за ступенем охоплення етапів інноваційного й життєвого циклу нового продукту, та, відповідно, варіантів комерціалізації інновацій;

2) уточнення та систематизація завдань маркетингу інновацій для виділених варіантів інноваційного процесу й варіантів комерціалізації інновацій;

3) уточнення завдань маркетингу інновацій на етапах життєвого циклу нового товару;

4) визначення особливостей виконання завдань маркетингу інновацій відповідно до стану споживчої готовності, в якому перебувають цільові споживачі нового товару (фактичні чи потенційні);

5) розроблення схеми управління вибором заходів маркетингового супроводу комерціалізації інноваційної продукції, що дає змогу узагальнено окреслити коло методів та інструментів маркетингу інновацій, які забезпечують маркетинговий супровід вибраних варіантів комерціалізації.

Розглянемо роль маркетингу (маркетингу інновацій) у виконанні робіт різних варіантів інноваційного процесу, що подані у табл. 1.

Літери у табл. 1 мають такі значення: м, с, в малі, середні та великі підприємства відповідно; 1і.ц., ..., 5і.ц. - номер етапу типового інноваційного циклу; 1ж.ц., ..., 4ж.ц. - номер етапу життєвого циклу товару. 
Варіанти інноваційного процесу

Таблиця 1

\begin{tabular}{|c|c|c|c|c|c|c|c|c|c|}
\hline \multirow[b]{3}{*}{$\begin{array}{c}\text { Номер варіанта } \\
\text { інноваційного процесу } \\
\text { та відповідного йому } \\
\text { типу інноваційної } \\
\text { стратегії }\end{array}$} & \multirow[b]{3}{*}{$\begin{array}{c}\text { Тип } \\
\text { інноваційного } \\
\text { бізнесу }\end{array}$} & \multicolumn{5}{|c|}{ Етапи інноваційного циклу } & & & \\
\hline & & \multirow[b]{2}{*}{ 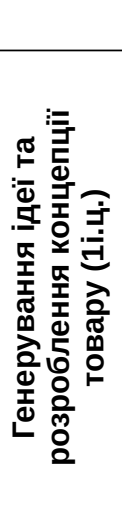 } & \multirow[b]{2}{*}{ 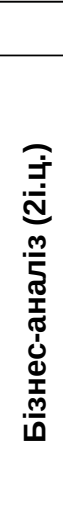 } & \multirow[b]{2}{*}{ 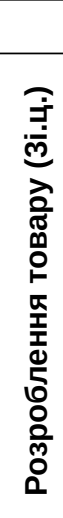 } & \multirow[b]{2}{*}{ 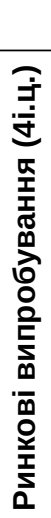 } & \multicolumn{4}{|c|}{ Етапи життєвого циклу } \\
\hline & & & & & & 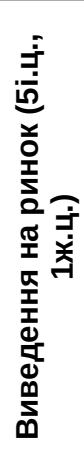 & 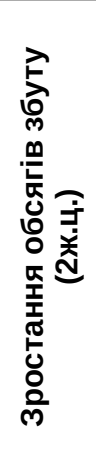 & 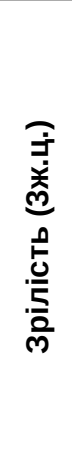 & 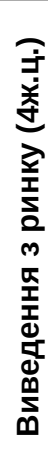 \\
\hline 1. Ліцензування & \multirow{3}{*}{ Венчурний } & $\mathrm{M}$ & & & & & & & \\
\hline 2. Імітаційна & & & \multicolumn{3}{|c|}{$M$} & & & & \\
\hline 3. Ліцензування & & \multicolumn{4}{|c|}{ M } & & & & \\
\hline 4. Імітаційна & Експлерент & & & & & M & & & \\
\hline 5. Нішера & Патієнт & & & & & & M & & \\
\hline 6. Традиційна (захисна) & Віолент & & & & & & & $\mathrm{B}, \mathrm{C}$ & \\
\hline 7. Нішера & Комутант & & & & & & & & $M$ \\
\hline 8. Імітаційна & \multirow{3}{*}{ Комбінований } & & & & & & & & \\
\hline 9. Наступальна & & \multicolumn{5}{|c|}{$B, C$} & & & \\
\hline 10. Захисна & & & & & & & & $\mathrm{B}, \mathrm{C}$ & \\
\hline
\end{tabular}

Джерело: побудовано авторами на основі джерел [20; 21]

Таблиця 2

Завдання маркетингу інновацій для різних варіантів інноваційного процесу

\begin{tabular}{|c|c|}
\hline \begin{tabular}{|c|} 
Варіант \\
інноваційного \\
процесу
\end{tabular} & Завдання маркетингу інновацій підприємства \\
\hline 1 & $\begin{array}{l}\text { Аналіз ринкових позицій підприємства. Аналіз тенденцій розвитку ринкових процесів. Аналіз } \\
\text { проблем споживачів продукції галузі підприємства (суміжних галузей) і визначення шляхів їх } \\
\text { подолання. Аналіз ринкових можливостей інноваційного розвитку підприємства (SWOT, Gap та } \\
\text { інші методи). Визначення потенційних покупців патенту й просування його на ринку. }\end{array}$ \\
\hline 2 & $\begin{array}{l}\text { Участь у розробленні концепції товару. Бізнес-аналіз і розроблення програми маркетингу } 3 \\
\text { просування на ринку нового товару (його очікувані характеристики визначені у концепції товару), } \\
\text { оцінювання можливості її реалізації. Ринкові випробування товару методом пробного маркетингу } \\
\text { чи іншими методами. Визначення потенційних партнерів для розгортання комерційного } \\
\text { виробництва товару. }\end{array}$ \\
\hline 3 & Поєднання робіт першого й другого варіантів інноваційного процесу. \\
\hline 4 & $\begin{array}{l}\text { Радикальна трансформація наявного чи формування нового ринку, фрормування первинного } \\
\text { попиту. Вжиття заходів комплексу маркетингу інновацій. Пошук партнера для впровадження. }\end{array}$ \\
\hline 5 & $\begin{array}{l}\text { Аналіз тенденцій розвитку ринку, включаючи аналіз споживачів, мотивів їх поведінки, конкурентів } \\
\text { та їх продукції, обсягів збуту тощо. Пошук нових сегментів чи ніш ринку. Модифрікація заходів } \\
\text { комплексу маркетингу задля підвищення конкурентоспроможності й охоплення нових сегментів } \\
\text { чи ніш ринку. Пошук партнера для впровадження (за необхідності). }\end{array}$ \\
\hline 6 & $\begin{array}{l}\text { Аналіз ринкових тенденцій. Маркетинговий контроль реалізації та прибутковості. Конкурентний } \\
\text { аналіз. Модифрікація заходів комплексу маркетингу задля підвищення конкурентоспроможності й } \\
\text { протидії конкурентам. Пошук нових ринків. }\end{array}$ \\
\hline 7 & $\begin{array}{l}\text { Пошук ніші ринку. Маркетинговий контроль реалізації та прибутковості. Модифрікація заходів } \\
\text { комплексу маркетингу. Вжиття заходів завершення життєвого циклу товару (вичерпання } \\
\text { можливостей). }\end{array}$ \\
\hline 8 & Поєднання робіт другого й четвертого варіантів інноваційного процесу. \\
\hline 9 & Поєднання робіт третього й четвертого варіантів інноваційного процесу. \\
\hline 10 & Поєднання робіт п'ятого, шостого й сьомого варіантів інноваційного процесу. \\
\hline
\end{tabular}

Джерело: побудовано авторами на основі джерела [6] 
Аналіз табл. 2 свідчить про те, що всі роботи маркетингу інновацій можна розділити на такі види:

- пов'язані 3 орієнтацію інноваційної діяльності підприємства на створення перспективних інновацій, які спрямовані на вирішення поточних i прогнозованих проблем фрактичних та потенційних споживачів, звичайно, при цьому створювані інновації повинні вирішувати проблеми підприємствінноваторів, а саме приведення увідповідність внутрішніх можливостей (потенціалу інноваційного розвитку) до зовнішніх, які генеруються ринком;

- пов'язані з формуванням і стимулюванням попиту на інновації, просуванням інновацій на ринок, моніторингом розвитку ситуації на ринку (задля своєчасного реагування на зміни умов зовнішнього макро- й мікросередовища), тобто роботи, що безпосередньо спрямовані на комерціалізацію інновацій.
Під час планування й вжиття заходів другого виду необхідно враховувати особливості сприйняття інновацій різним групами споживачів (табл. 3). Відповідно до табл. 3 на етапах життевого циклу різними будуть завдання комплексу маркетингу інновацій.

У табл. 2 систематизовано завдання маркетингу інновацій стосовно виділених у табл. 1 варіантів інноваційного процесу.

Необхідним також $€$ врахування стану споживчої готовності, у якому перебувають цільові споживачів (фрактичні чи потенційні). Від цього залежать сила впливу заходів комплексу маркетингових комунікацій (комплексу маркетингу загалом), тривалість часу фрормування й стимулювання попиту, бюджет комплексу маркетингу тощо (рис. 1). Стани споживчої готовності подано за Ф. Котлером [10]: загальні уявлення про товар $\left(C_{1}\right)$; знання характеристик і способів використання товару $\left(C_{2}\right)$;

Таблиця 3

Завдання маркетингу інновацій на етапах життєвого циклу нового товару

\begin{tabular}{|l|c|c|c|c|}
\hline \multirow{2}{*}{$\begin{array}{c}\text { Tип споживачів, } \\
\text { їх частка [10] }\end{array}$} & $\begin{array}{c}\text { виведення } \\
\text { на ринок }\end{array}$ & зростання збуту & зрілість & виведення з ринку \\
\cline { 2 - 5 } & $\begin{array}{c}\text { 1. Формування } \\
\text { первинного попиту }\end{array}$ & & & \\
\hline $\begin{array}{l}\text { Ранні послідовники, } \\
16 \%\end{array}$ & & $\begin{array}{c}\text { 2. Формування } \\
\text { вибіркового попиту }\end{array}$ & & \\
\hline Рання більшість, 34\% & & $\begin{array}{c}\text { 3. Підтримання } \\
\text { попиту }\end{array}$ & $\begin{array}{c}\text { 4. Підтримання } \\
\text { попиту }\end{array}$ & \\
\hline Пізня більшість, 34\% & & $\begin{array}{c}\text { П. Підтримання } \\
\text { попиту }\end{array}$ & \\
\hline Аутсайдери, 13,5\% & & & & $\begin{array}{c}\text { 6. Вичерпання } \\
\text { можливостей }\end{array}$ \\
\hline
\end{tabular}

Джерело: побудовано авторами

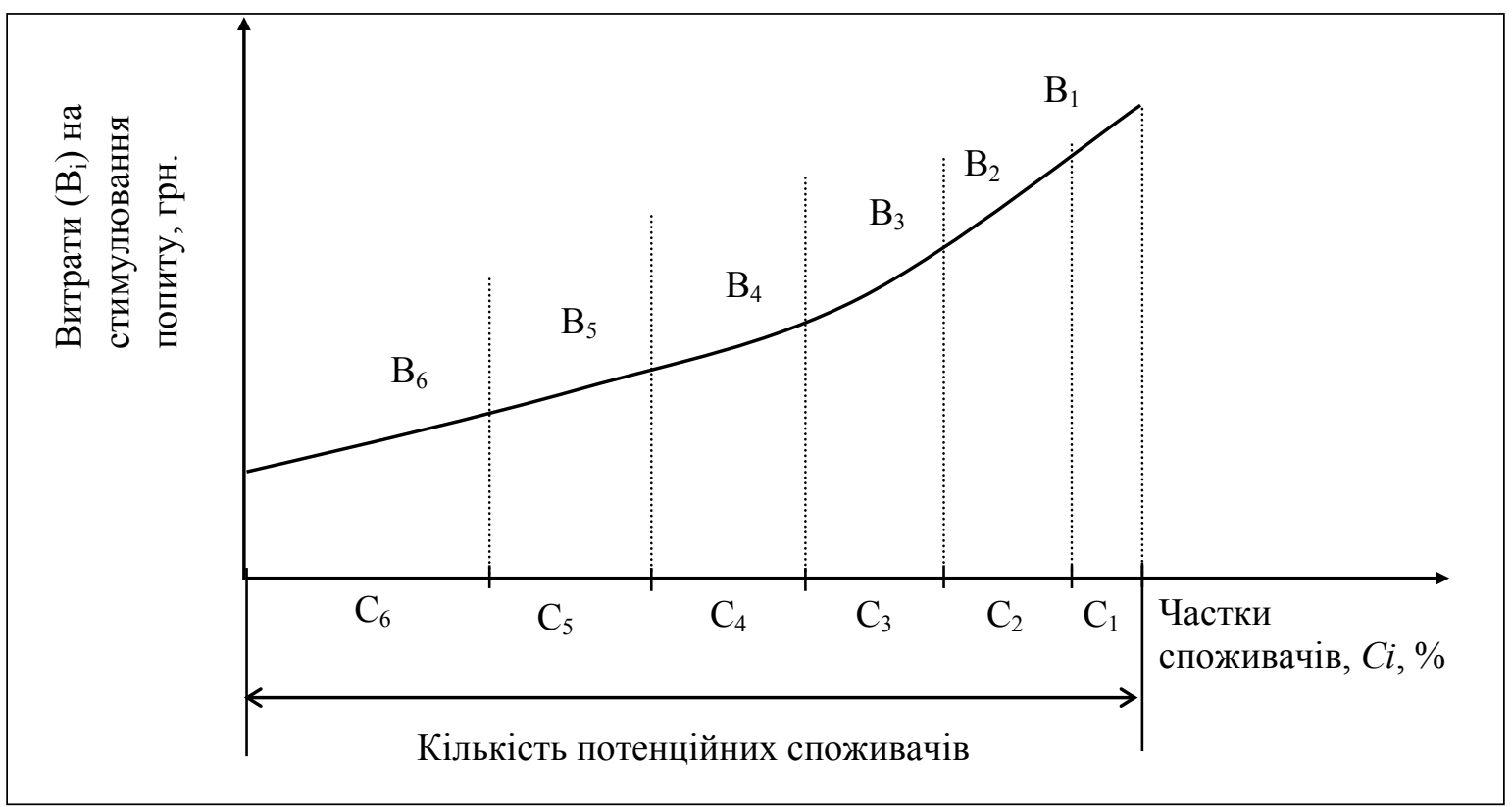

Рис. 1. Витрати на формування й стимулювання збуту залежно від стану споживчої готовності цільової аудиторії

Джерело: складено авторами за джерелом [3] 
Таблиця рішень щодо вибору заходів маркетингового супроводу

Таблиця 4 комерціалізації інноваційної продукції

\begin{tabular}{|c|c|c|c|c|c|c|c|c|}
\hline \multirow{2}{*}{$\begin{array}{c}\text { Тип } \\
\text { інноваційного } \\
\text { бізнесу }\end{array}$} & \multicolumn{3}{|c|}{$\begin{array}{c}\text { Розмір } \\
\text { підприємства- } \\
\text { інноватора }\end{array}$} & \multirow{2}{*}{$\begin{array}{l}\text { Інноваційна } \\
\text { стратегія, } \\
\text { табл. } 1\end{array}$} & \multirow{2}{*}{$\begin{array}{c}\text { Завдання } \\
\text { маркетингу, } \\
\text { табл. } 2\end{array}$} & \multirow{2}{*}{$\begin{array}{c}\text { Завдання } \\
\text { маркетингу } \\
\text { на етапі } \\
\text { ж. ц., табл. } 3 \\
\end{array}$} & \multirow{2}{*}{$\begin{array}{c}\text { Стан } \\
\text { споживчої } \\
\text { готовності, } \\
\text { рис. } 1 \\
\end{array}$} & \multirow{2}{*}{$\begin{array}{c}\text { Наголос у } \\
\text { маркетингу } \\
\text { інновацій }\end{array}$} \\
\hline & $M$ & C & B & & & & & \\
\hline \multirow{3}{*}{ Венчурний } & + & & & 1 & 1 & & $\begin{array}{l}\text { Формування } \\
\text { споживчої } \\
\text { готовності } \\
\end{array}$ & $\begin{array}{c}\text { Аналіз, } \\
\text { просування }\end{array}$ \\
\hline & + & & & 2 & 2 & & $\begin{array}{l}\text { Формування } \\
\text { споживчої } \\
\text { готовності } \\
\end{array}$ & $\begin{array}{c}\text { Аналіз, } \\
\text { просування }\end{array}$ \\
\hline & + & & & 3 & 3 & & $\begin{array}{c}\text { Формування } \\
\text { споживчої } \\
\text { готовності }\end{array}$ & $\begin{array}{c}\text { Аналіз, } \\
\text { просування }\end{array}$ \\
\hline Експлерент & + & & & 4 & 4 & 1 & \begin{tabular}{|c|} 
Формування \\
й підвищення \\
рівня споживчої \\
готовності \\
\end{tabular} & $\begin{array}{c}\text { Формування } \\
\text { ринку, пошук } \\
\text { партнера }\end{array}$ \\
\hline Патієнт & + & & & 5 & 5 & 2,3 & $\begin{array}{c}\text { Підвищення } \\
\text { рівня споживчої } \\
\text { готовності } \\
\end{array}$ & $\begin{array}{c}\text { Диверсифікація } \\
\text { ринку, продукту, } \\
\text { маркетингу }\end{array}$ \\
\hline Віолент & & + & + & 6 & 6 & 4,5 & $\begin{array}{l}\text { Підтримання } \\
\text { споживчої } \\
\text { готовності } \\
\end{array}$ & $\begin{array}{l}\text { Підтримання } \\
\text { попиту, аналіз }\end{array}$ \\
\hline Комутант & + & & & 7 & 7 & 6 & $\begin{array}{c}\text { Підтримання } \\
\text { споживчої } \\
\text { готовності } \\
\end{array}$ & $\begin{array}{l}\text { Вичерпання } \\
\text { можливостей }\end{array}$ \\
\hline \multirow{3}{*}{ Комбінований } & & + & + & 8 & 8 & 1 & $\begin{array}{c}\text { Формування } \\
\text { й підвищення } \\
\text { рівня споживчої } \\
\text { готовності } \\
\end{array}$ & $\begin{array}{l}\text { Формування } \\
\text { ринку, аналіз }\end{array}$ \\
\hline & & + & + & 9 & 9 & 1 & \begin{tabular}{|c|} 
Формування \\
й підвищення \\
рівня споживчої \\
готовності \\
\end{tabular} & $\begin{array}{l}\text { Формування } \\
\text { ринку, аналіз }\end{array}$ \\
\hline & & + & + & 10 & 10 & $2-6$ & $\begin{array}{c}\text { Підвищення } \\
\text { рівня й } \\
\text { підтримання } \\
\text { споживчої } \\
\text { готовності }\end{array}$ & $\begin{array}{c}\text { Диверсифрікація } \\
\text { ринку, продукту, } \\
\text { маркетингу, } \\
\text { підтримання } \\
\text { попиту, аналіз }\end{array}$ \\
\hline
\end{tabular}

Джерело: розроблено авторами

прихильність до товару, тобто у споживачів сформувалося сприятливе ставлення до товару $\left(C_{3}\right)$; надання переваги перед аналогами $\left(C_{4}\right)$; впевненість у необхідності товару $\left(C_{5}\right)$; готовність придбати товар негайно $\left(C_{6}\right)$.

Узагальнення викладеного дало змогу розробити схему управління вибором заходів маркетингового супроводу комерціалізації інноваційної продукції (табл. 4).

Слід зазначити, що табл. 4 дає змогу узагальнено окреслити коло методів та інструментів маркетингу інновацій, які забезпечують маркетинговий супровід вибраних варіантів комерціалізації.

Їх уточнення рекомендується виконувати з урахуванням специфріки конкретного підприємстваінноватора, виду його продуктових (товарних) інновацій, цільового ринку чи сегментів тощо.

Враховуючи специсріку сучасного етапу розвитку світової та вітчизняної економіки (завершення 5-го і перехід до початку 6-го технологічних укладів, початок Четвертої промислової революції тощо), зниження дієвості традиційних інструментів маркетингу, доцільним вважаємо застосування новітніх видів та інструментів [20; 21].

Висновки 3 проведеного дослідження. Підбиваючи підсумки, маємо зазначити, що авторами розроблена схема управління вибором заходів маркетингового супроводу різних варіантів комерціалізації інноваційної продукції підприємства, які виділені заступенем охоплення етапів інноваційного й життєвого циклу продуктової інновації.

Вона дає змогу узагальнено окреслити коло методів та інструментів маркетингу інновацій, які забезпечують маркетинговий супровід вибраних варіантів комерціалізації. Запропоновано підхід до врахування в заходах маркетингу інновацій особливостей виконання його завдань на етапах життєвого циклу нового товару, а також урахування 
стану споживчої готовності цільових споживачів. Практична реалізація отриманих результатів дає змогу підвищити ефективність маркетингового супроводу комерціалізації інновацій в умовах трансформації технологічних укладів.

Подальші дослідження повинні бути спрямовані на розроблення засад організаційно-економічного механізму управління на основі маркетингу комерціалізації інновацій підприємств.

\section{БІБЛІОГРАФІЧНИЙ СПИСОК:}

1. Бутко М.П., Попело О.В. Комерціалізація результатів науково-технічної діяльності в умовах поглиблення інтеграційних процесів. Проблеми i перспективи економіки та управління. 2015. № 1. С. 7-20.

2. Євтушевська О.В. Комерціалізація інноваційних розробок у контексті сприйняття споживачами товарів-новинок. Інвестиції: практика та досвід. 2019. № 2. С. 38-41.

3. Ілляшенко С.М., Прокопенко О.В. Формування ринку екологічних інновацій: економічні основи управління : монографрія / за ред. С.М. Ілляшенка. Суми : ВТД «Університетська книга», 2002. 250 с.

4. Ілляшенко С.М., Рудь М.П. Маркетингові інновації в інноваційній діяльності підприємств України. Ефрективна економіка. 2017. № 6. URL: http://www. economy.nayka.com.ua/?op=1\&z=5626 (дата звернення: 10.01.2020).

5. Ілляшенко С.М., Рудь М.П. Новітні види маркетингу в умовах випереджаючого розвитку: еволюція, сутність, умови застосування. Науковий вісник УжНУ. Серія: Міжнародні економічні відносини та світове господарство. 2019. Вип. 24. Ч. 2. С. 37-42.

6. Ілляшенко С.М. Теоретико-методичні засади товарної інноваційної політики підприємства. Маркетинг і менеджмент інновацій. 2011. № 2. С. 13-26.

7. Калиниченко М.П. Маркетинг комерціалізації результатів інноваційної діяльності в промисловості. Маркетинг і менеджмент інновацій. 2012. № 4. C. 43-50.

8. Карпенко А.В., Кононенко Ю.С. Стратегічне значення комерціалізації для інноваційного розвитку національної економіки. Економіка і організація управління. 2017. № 1 (25). С. 190-201.

9. Косенко О.П. Комерціалізація інтелектуальноінноваційних технологій : монографрія. Харків : НТУ «ХП|», 2015. 599 c.

10. Котлер Ф. Основы маркетинга. Москва : Бизнес-книга, 1995. 698 с.

11. Кузьмін О.Є., Косцик Р.С. Вибір методів комерціалізації інноваційної продукції підприємств. Економіка та держава. 2013. № 9. С. 6-8.

12. Кузьомко В.М. Інноваційна діяльність та комерціалізація інновацій: виклики та загрози. Інноваційне підприємництво: стан та перспективи розвитку : збірник матеріалів II Всеукраїнської науково-практичної конференції, 29-30 березня 2017 р. I Міністерство освіти і науки України, ДВНЗ «Київський національний економічний університет ім. В. Гетьмана» [та ін.] ; оргком.: Г.О. Швиданенко (голова) [та ін.]. Київ : КНЕУ, 2017. С. 167-169.
13. Мельник Ю.М., Сагер Л.Ю., Сигида Л.О. Теоретичні аспекти фрормування стратегій комерціалізації інноваційної продукції. Вісник ОНУ ім. І.І. Мєчнікова. 2019. Т. 24. Вип. 1 (74). С. 69-73.

14. Мирощенко Н.Ю. Комерціалізація високотехнологічної продукції промислових підприємств : дис. ... канд. екон. наук : спец. 08.00.04 ; Національний університет «Львівська політехніка». Львів, 2018. 216 c.

15. Олефріренко О.М. Комерціалізація інновацій в Україні: передумови та вітчизняні реалії. Економіка і суспільство. 2016. Вип. 6. С. 197-202.

16. Олесріренко О.М. Комерціалізація інновацій як об'єктивний чинник ефективного фрункціонування промислового підприємства. Економіка та управління підприємствами. 2016. Вип. 5. С. 186-189.

17. Плахотнік О.О. Теоретичні засади фрормування механізму комерціалізації інноваційних технологій. Технологический аудит и резервы производства. 2015. № 5 (25). С. 54-57.

18. Попова А.О. Комерціалізація результатів інноваційної діяльності крізь призму моделі «Потрійна спіраль». Економічні інновації. 2015. № 60. Кн. II. C. 113-120.

19. Тимофеев Д.В. Динамика экономического эфрфекта в процессе управления жизненным циклом инноваций при их коммерциализации. БизнесИнфорорм. 2017. № 1. С. 56-60.

20. Шипулина Ю.С., Ілляшенко Н.С., Ілляшенко С.М. Управління інноваційним розвитком підприємства на основі його інноваційної культури. Інституціональна модель інноваційної економіки : колективна монограсрія / за ред. В.І. Ляшенка, О.В. Прокопенко, В.А. Омельяненка. Київ : НАН України, Інститут економіки промисловості, 2019. С. 97-113.

21. Illiashenko S.M. Innovative process rational choice grounding in organization. Marketing and Management of Innovation. 2015. № 2. P. 11-20.

\section{REFERENCES:}

1. Butko M.P., Popelo O.V. (2015) Komertsializatsiia rezultativ naukovo-tekhnichnoi diialnosti $v$ umovakh pohlyblennia intehratsiinykh protsesiv [Commercialization of the results of scientific and technological activities under integration processes deepening]. Problems and Prospects of the Economy and Management. Vol. 1, pp. 7-20.

2. levtushevska O.V. (2019) Komertsializatsiia innovatsiinykh rozrobok u konteksti spryiniattia spozhyvachamy tovariv-novynok [Commercialization of innovations in a context of new products perception]. Investytsiyi: praktyka ta dosvid. Vol. 2, pp. 38-41.

3. Illiashenko S.M., Prokopenko O.V. (2002) Formuvannia rynku ekolohichnykh innovatsii: ekonomichni osnovy upravlinnia. Sumy : VTD "Universytetska knyha". 2002. 250 p.

4. Illiashenko S.M., Rud M.P. (2017) Marketynhovi innovatsii $v$ innovatsiinii diialnosti pidpryiemstv Ukrainy [Marketing innovations in the innovative activity of the Ukrainian enterprises]. Efektyvna ekonomika. Vol. 6. Available at: http://www.economy. nayka.com.ua/?op=1\&z=5626 (accessed: 10 January 2020). 
5. Illiashenko S.M., Rud M.P. (2019) Novitni vydy marketynhu $v$ umovakh vyperedzhaiuchoho rozvytku: evoliutsiia, sutnist, umovy zastosuvannia [The newest types of marketing in the conditions of future development: evolution, essence, application conditions]. Uzhgorod National University Herald. International Economic Relations And World Economy. Vol. 24. Iss. 2, pp. 37-42.

6. Illiashenko S.M. (2011) Teoretyko-metodychni zasady tovarnoi innovatsiinoi polityky pidpryiemstva [Theoretical and methodical foundations of commodity innovation policy of the enterprise]. Marketing and Management of Innovations. Vol. 2, pp. 13-26.

7. Kalynychenko M.P. (2012) Marketynh komertsializatsii rezultativ innovatsiinoi diialnosti $v$ promyslovosti. [The marketing of innovation activity results commercialization in industry]. Marketing and Management of Innovations. Vol. 4, pp. 43-50.

8. Karpenko A.V., Kononenko Yu.S. (2017) Stratehichne znachennia komertsializatsii dlia innovatsiinoho rozvytku natsionalnoi ekonomiky [Strategic importance of commercialization for innovative development of national economics]. Economics and organization of management. Vol. 1 (25), pp. 190-201.

9. Kosenko O.P. (2015) Komertsializatsiia intelektualno-innovatsiinykh tekhnolohii [Commercialization of intellectually innovative technologies]. Kh. : NTU "KhPI", 599p.

10. Kotler F. (1995) Osnovy marketynha [Fundamentals of Marketing]. M. : Byznes-knyha. 698 p.

11. Kuzmin O.le., Kostsyk R.S. (2013) Vybir metodiv komertsializatsii innovatsiinoi produktsii pidpryiemstv [The choice of commercialization methods of enterprises innovative products]. Ekonomika ta derzhava. Vol. 9, pp. 6-8.

12. Kuzomko V.M. (2017) Innovatsiina diialnist ta komertsializatsiia innovatsii: vyklyky ta zahrozy. Innovatsiine pidpryiemnytstvo: stan ta perspektyvy rozvytku [Innovation and the commercialization of innovation: challenges and threats]. Kyiv : KNEU, pp. 167-169.

13. Melnyk Yu.M., Saher L.Iu., Syhyda L.O. (2019) Teoretychni aspekty formuvannia stratehii komertsializatsii innovatsiinoi produktsii [Theoretical aspects of strategies forming for innovative products commercial- ization]. Odesa National University herald. Vol. 1 (74). Iss. 24, pp. 69-73.

14. Myroshchenko N.Iu. (2018) Komertsializatsiia vysokotekhnolohichnoi produktsii promyslovykh pidpryiemstv : dys. ... kand. ekon. nauk : 08.00.04. Natsionalnyi universytet "Lvivska politekhnika". Lviv, 216 p.

15. Olefirenko O.M. (2016) Komertsializatsiia innovatsii v Ukraini: peredumovy ta vitchyzniani realii [Innovations commercialization in Ukraine: preconditions and domestic realities]. Economy and Society. Vol. 6, pp. 197-202.

16. Olefirenko O.M. (2016) Komertsializatsiia innovatsii yak obiektyvnyi chynnyk efektyvnoho funktsionuvannia promyslovoho pidpryiemstva. [Commercialization of innovation as an objective factor in the efficient functioning of an industrial enterprise]. Ekonomika ta upravlinnia pidpryiemstvamy. Vol. 5, pp. 186-189.

17. Plakhotnik O.O. (2015) Teoretychni zasady formuvannia mekhanizmu komertsializatsii innovatsiinykh tekhnolohii [Theoretical bases of formation of commercialization mechanism of innovative technologies]. Technology Audit And Production Reserves. Vol. 5 (25), pp. 54-57.

18. Popova A.O. (2015) Komertsializatsiia rezultativ innovatsiinoi diialnosti kriz pryzmu modeli "Potriina spiral" [Commercialization of results of innovation activity through the prism of the Triple Helix Model]. Economic innovations. Vol. 60. Iss. 2, pp. 113-120.

19. Tymofeev D.V. (2017) Dinamika ekonomicheskogo effekta $v$ protsesse upravleniya zhiznennyim tsiklom innovatsiy pri in kommertsializatsii [Dynamics of the Economic Effect in the Process of Managing the Life Cycle of Innovations in Terms of Their Commercialization]. Business-Inform. Vol. 1, pp. 56-60.

20. Shypulyna Yu.S., Illiashenko N.S., Illiashenko S.M. (2019) Upravlinnia innovatsiinym rozvytkom pidpryiemstva na osnovi yoho innovatsiinoi kultury. Instytutsionalna model innovatsiinoi ekonomiky : kolektyvna monohrafiia. Kyiv : NAN Ukrainy, In-t ekonomiky prom-sti, pp. 97-113.

21. Illiashenko S.M. (2015) Innovative process rational choice grounding in organization. Marketing and Management of Innovation. Vol. 2. pp. 11-20. 